\title{
A Girl's Education
}

\author{
Claudia Mitchell and Jacqueline Reid-Walsh
}

\section{$\cos 80$}

The first "White House Research on Girls" Conference took place on 28 April 2014, in Washington, DC. At this event the Girls Research Coalition was formed, and the White House Council on Women and Girls also announced the establishment of the Girls Portal, ${ }^{1}$ a clearinghouse for research on girls, hosted by Re:Gender ${ }^{2}$ (formerly known as The National Council for Research on Women, Inc.), and meant to facilitate the sharing of existing research on girls, and to provide opportunities to explore new directions in research. This initiative is an important one for ensuring that the burgeoning research on girlhood reaches the many different audiences who need to have access to its findings. As the editors of GHS, we strongly endorse the establishment of the Girls Research Coalition and the Girls Portal.

A critical area of this fast-growing research relates to girls and education. This interest, both in the formal sector of schooling and in the landscape of the everyday (and, more especially, in media representations) is wide-spread. Although this issue of GHS started out as one of our regular unthemed issues, the range of articles from a number of different countries- the US, Hong Kong, Malawi, and Australia-dealing with topics from contemporary representations of toddlers on a reality television series, to the interrogation of "the college woman" in nineteenth and early twentieth century higher education, nicely complement each other in relation to what we refer to here as "a girl's education." As the articles point out, a girl's education can take place in school, in after-school programs, and beyond school. They address a number of key questions: What shapes and reshapes a girl's education? What is the impact of popular culture particularly through what might be termed the "Hollywood curriculum?" What are the entry points both inside schools and in society more broadly that make it possible to rethink the ways in which girls can actively give shape to social change? It is no accident that we begin and end the collection of articles with contributions that place media representations squarely in the picture of informal 
education, starting with Eva Lupold's "Adolescence in Action: Screen Narratives of Girl Killers" and ending with Chrstina Hodel's "Performing the Ultimate Grand Supreme: Approval, Gender and Identity in Toddlers \& Tiaras." The lead article by Eva Lupold, in taking on the contemporary girl action-hero in such films as Kick-Ass, Hanna, True Grit, and The Hunger Games, highlights the reasons why films with adolescent action heroines are increasingly popular with both male and female audiences. Offering in her analysis a comprehensive review of the history of the representation of adolescent female characters in film, the author highlights new anxieties about girls themselves in relation to panics about the changing nuclear family with its "unreliable mothers" and "failed fathers." As Lupold writes, "If films imply that girls cannot find their own identities without the help of parental figures or disciplinary institutions such as the school, or if they suggest that adolescents who remain outside rigid social structures are abnormal, then they underestimate girls' potential to become active agents in their own identity-formation." She concludes by noting that "[a]lthough there are many progressive messages in contemporary films featuring adolescent action heroines, audiences need to become more aware of simultaneously regressive messages about girlhood, motherhood, and fatherhood in such movies, while paying attention to the cultural anxieties these films also exhibit about the demise of the nuclear family."

Then Leigh Moscowitz and Micah Blaise Carpenter's article "Girl Zines at Work: Feminist Media Literacy Education with Underserved Girls" reports on a study in which they engaged fourth and fifth grade girls of color in an after-school media literacy project during which the girls produced zines. As the authors point out, while there are numerous studies of cultural production that involve middle and upper-class children, typically girls from more marginalized families are often left out, particularly because of the difficulty of actually participating in an extra-curricular initiative such as the one described in the article. In reflecting on the strengths and challenges of The Zines Club and its potential to engage underserved girls in thinking critically about media representations but also about girlhood, the authors pose the critical question: "What could be achieved through more intensive, lengthy initiatives, headed by certified public school teachers with greater funding and more institutional support?" They conclude that the possibilities "call for a collective response from educators, activists, and researchers."

Fiona MacDonald reports on her work with younger girls in her article "Negotiations of Identity and Belonging: Beyond the Ordinary Obviousness of Tween Girls' Everyday Practices" which focuses on the complexity within 
the ordinary school routine of a group of 11- to 12-year-old girls in a grade 6 class in Melbourne, Australia. MacDonald engages in a reflective account of an ethnographic study she undertook of the "everyday practices" of these girls. MacDonald analyzes how girls work to negotiate their identity within social groups in order to develop a sense of self outside of their families. She analyses the strategic negotiations and the different perspectives of members of a friendship group and demonstrates that there is "valuable information to be gained from analysing the complex meanings of the girls' everyday practices and considerations and negotiations of belonging."

Shifting the focus from a girl's contemporary education to the historical and into the sphere of higher education, Tamara Beauboeuf-Lafontant, in her article, "Becoming Jane Addams: Feminist Developmental Theory and 'The College Woman"' writes about Addams as a sociologist and major reformer working during the American Progressive Era of 1890 to 1920. The author draws on "contemporary feminist developmental theory that examines the ways in which girls and women encounter and resist socialization into patriarchal womanhood." Beauboeuf-Lafontant's focus is on Addams's recognition that seeing adolescence as the bridge between "the differing statuses of girlhood and womanhood" worked to turn "voiceful girls" into "compliant women." Beauboeuf-Lafontant offers striking "parallels between Addams's presentation of 'the college woman' and the developmental strengths, struggles, and resistance of contemporary girls and adolescents" bringing into focus "the socially transformative potential of young women."

Martha Kamwendo's article, "Malawian Teachers' Perceptions of Gender and Achievement in the Context of Girls' Underachievement" seeks to understand the role teachers play in the formation of gendered identities in their pupils which, in most cases, affect, in turn, their academic underachievement. She describes how secondary school subjects are gendered with most, if not all, teachers holding stereotypical beliefs about the academic abilities of females (lower) and males (higher), with the result that boys and girls are channeled into stereotypical educational paths. Kamwendo describes and analyses "the role teachers play in the formation of gendered identities among pupils," and, in doing so, she exposes "the tensions and contradictions girls experience in succeeding academically." She concludes by making proposals for policy and practice change at the institutional and government level to enable more girls to achieve their academic potential.

In her article "Mapping the Terrains for Girlhood in Hong Kong" Chui Ping Iris Kam proposes that popular culture texts that appeal to girls should be incorporated into the secondary school curriculum. While the 
official curriculum represents girls as women-to-be within a very restrictive framework, popular culture texts in the curriculum would provide alternative models of young femininity for girls. Kam offers, as an example, "the Chinese version of CosmoGIRL! [because it] discusses careers, success and money." This, she suggests will "help equip teenage girls with the skills necessary to compete in the capitalist market but [will] also ... widen their options in life" in providing "an oppositional discourse to the official school curriculum."

In the final full-length article, we see a return to media representations in Christina Hodel's "Performing the Ultimate Grand Supreme: Approval, Gender and Identity in Toddlers \& Tiaras." Hodel looks at the underlying narrative of the TV series in terms of the young girls' performance of their nascent gender identity. She combines discourse analysis with an empirical approach in order to answer her research question: "How are gender and identity constructed so as to receive approval from adults and peers via performance in a pageant for the youngest cast members in Toddlers \& Tiaras?" In her analysis Hodel stresses how, in order to win the grand prize, the girls are hyper-feminized in terms of their appearance and performance. She concludes her article with a brief consideration of the possible ill effects on young girls who participate in the processes and rituals of such pageantrelated hypersexualization.

Following the peer reviewed articles, we include a visual essay by Fatuma Chege, Lucy Maina, Claudia Mitchell, and Margot Rothman (in alphabetical order) "A Safe House? Girls' Drawings on Safety and Security in Slums in and Around Nairobi." The essay includes a sub-set of a collection of drawings produced by girls between the ages of 8 and 14 in a two-year study of housing and security in the slums and informal settlements of Kenya's capital city, Nairobi, that link child labour and domestic violence. The collection highlights the challenges that the girls face but also offers an example of a solution in the call to "educate parents."

This issue of GHS, broadly based, however accidentally, on the theme of a girl's education, also includes reviews of two books, both by leading authors in the area of girlhood studies in the US, Jessica K. Taft, and Rebecca Hains. The title of Emily Bent's review of Jessica K. Taft's (2011) Building Activist Communities: The Rebel Girls Guide to Creating Social Change says it all: in calling her review "Building Activist Communities: The Rebel Girls Guide to Creating Social Change" Bent points to what she calls the "single and undeniable truth" of this book: "teenage girls are powerful political actors with valuable insights and stories to share." She makes it clear that 
"Rebel Girls is a valuable and accessible read for social movement actors, feminists, girls' studies scholars, and activists alike."

Jessalynn Keller, in her review of Rebecca Hains's (2012) Growing Up with Girl Power: Girlhood on Screen and in Everyday Life, reminds us that the concept of girl power was a formative part of the biography of many of today's women. Keller locates this study within a growing body of work on the topic and applauds Hains on enabling the young informants she works with to interpret and negotiate the commercialized girl power messages found in the girl hero television shows. Keller observes that a key strength is Hains's scrupulous and detailed ethnographic work that is so clearly detailed that the book could be used as an accessible guide for those doing ethnographic work with girls. Moreover, Keller concludes that Hains's book should be regarded as a core text for scholars of girls' popular and media culture.

As this issue of Girlhood Studies goes to press, we are excited to announce that starting with Volume 8, we will be publishing three issues a year instead of two. In line with new initiatives such as the Girls Research Coalition and the well-established International Girls Studies Association, this growth of Girlhood Studies demonstrates and celebrates the significance of new scholarship in the area of Girlhood Studies.

\section{Notes}

1. Portal https://empatsy.wufoo.com/forms/girls-research-coalition-research-portal/

2. http://www.regender.org/about-regender 